\title{
"Multilevel transfer of innovations: Cognitive modeling to decision support in managing the economic growth"
}

\author{
Olena Shkarupa (D https://orcid.org/0000-0002-8990-0886 \\ R https://publons.com/researcher/1711184/olena-shkarupa/ \\ AUTHORS \\ Viktoriia Boronos (D https://orcid.org/0000-0003-3847-9830 \\ R http://www.researcherid.com/rid/F-8983-2019 \\ Dmytro Vlasenko \\ Kostiantyn Fedchenko
}

Olena Shkarupa, Viktoriia Boronos, Dmytro Vlasenko and Kostiantyn Fedchenko (2021). Multilevel transfer of innovations: Cognitive modeling to decision support in managing the economic growth. Problems and Perspectives in Management, 19(1), 151-162. doi:10.21511/ppm.19(1).2021.13

NUMBER OF REFERENCES

41

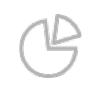

NUMBER OF FIGURES

3

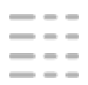

NUMBER OF TABLES

2

(C) The author(s) 2021. This publication is an open access article. 


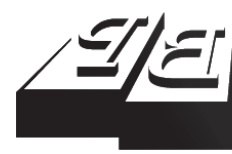

BUSINESS PERSPECTIVES

(O)

LLC "CPC "Business Perspectives" Hryhorii Skovoroda lane, 10, Sumy, 40022, Ukraine www.businessperspectives.org

Received on: $24^{\text {th }}$ of December, 2020 Accepted on: $4^{\text {th }}$ of February, 2021 Published on: $19^{\text {th }}$ of February, 2021

๑ Olena Shkarupa, Viktoriia Boronos, Dmytro Vlasenko, Kostiantyn Fedchenko, 2021

Olena Shkarupa, Doctor of Economics, Professor, Department of Economics, Entrepreneurship and Business Administration, Sumy State University, Ukraine. (Corresponding author)

Viktoriia Boronos, Doctor of Economics, Professor, Sumy State University, Ukraine.

Dmytro Vlasenko, Ph.D., Sumy State University, Ukraine.

Kostiantyn Fedchenko, Ph.D. Student, Sumy State University, Ukraine.
Olena Shkarupa (Ukraine), Viktoriia Boronos (Ukraine), Dmytro Vlasenko (Ukraine), Kostiantyn Fedchenko (Ukraine)

MULTILEVEL TRANSFER

OF INNOVATIONS: COGNITIVE MODELING TO DECISION SUPPORT IN MANAGING THE ECONOMIC GROWTH

\begin{abstract}
An essential aspect of the country's economic growth is the transfer of innovation, which is very important nowadays. The innovative projects can be implemented through it at the level of households, companies, institutions, and local communities. The transfer of innovations is intended to cause a cumulative effect and stimulate economic growth. It is important to determine the influence of different factors on this process and consider the feedbacks in the "enterprise-region-state" system, which will increase the level of control over the process. The paper aims to find scientific instruments for managing the multilevel transfer of innovations, representing the connections between factors that act as catalysts/inhibitors of that process. The proposed methodology uses systems analysis, indicative analysis, and cognitive modeling (Fuzzy Cognitive Maps (FCM)). Based on the study results, a cognitive model was formed based on identifying the "strength of impact" of connections between elements that determine the level of influence of the micro- and macro-environment factors of the innovation multilevel transfer. From a practical point of view, this allows obtaining forecasts of its behavior under different management actions. To implement the research results, it is necessary to determine management tools that will allow stakeholders in the system "enterpriseregion-state" to make a transfer of innovations most effective. It demonstrates the need for further research in this area and assessing the potential consequences of management decisions for economic growth.
\end{abstract}

Keywords

JEL Classification

complex systems, innovations, feedback, system connections, FCM, Ukraine

\section{INTRODUCTION}

Economic growth is a part of the highly targeted, sustainable development concept that is still a highly discussed issue for Ukraine and Europe. Innovations stimulate the increase of economic growth in the business sector and at the global level. Today in Ukraine, it is essential to stimulate entrepreneurial and social activities to solve the problems of modernizing worn-out and obsolete equipment, producing products and goods whose resources are costly and relatively not competitive in the world market. To overcome these problems, it is necessary to solve them using effective managerial control, especially in the sphere of transfer of innovations. One of the main economic growth factors in highly developed countries is government support for implementing innovations and goal setting for the effectiveness of innovation activities. The European experience of supporting innovation activities shows that by scaling innovations, it is possible to achieve economic growth in the country due to the chain reaction of innovative activities (Jordan, 2014; Kaiser \& Prange-Gstöhl, 2013; Zakutniaia \& Hayriyan, 2017). In Germany, they use state benefits, allow spending subsidies on new equipment and technologies, and receive con- 
tributions to develop enterprises and labor resources (EC, 2018). Also, a standard instrument in the innovation development sphere is soft loans, provided subject to financing by the owner of $50 \%$ of the innovation project's funds, providing up to EUR 100 thousand of soft loans to small and medium-sized enterprises. This incentive system allows for $13 \%$ of the turnover of innovation (with the total turnover in the country) with an average indicator in the European Union of $11.9 \%$. For example, in the USA, corporate income tax is reduced to $10 \%$ of the total investment cost in innovative projects (EC, 2018).

So, the question is how to identify the most significant causes and weaknesses in the "company-regionstate" system, influencing which the government can achieve greater efficiency. This study aims to contribute by proposing to form a methodology for analyzing the multilevel perspective on the transfer of innovations in Ukraine based on the cognitive approach, which has not yet been applied to government regulation procedures. The authors will analyze the external and internal factors of effective transfer of innovations, which will show how exactly it is necessary to develop tools for its regulation when focusing on economic growth, depending on the specifics of relationships in the "company-region-state" system and the level of management.

\section{THEORETICAL BASIS}

Nowadays, a high level of innovative development becomes possible due to the transfer of innovations, allowing regulating the relationship between science and industry. It is aimed at introducing new techniques and technologies in all functional subsystems of the economy. In theoretical terms, the impact of the transfer of innovative products to the market was studied in the works of such scientists as Illiashenko et al. (2019), Peshko and Nazarenko (2006), Chukhray (2017), Porter (1993), Fonshteyn (1995), Kanishchenko et al. (2019), and others.

Jordan (2014) notices that innovation is a phased process that must end in commercial success. The transfer of innovation entails income generation, job creation, and accumulation of intangible assets. He views innovation as a process in terms of the emergence of new value in the market, considering the needs of stakeholders - investors, regulators, and consumers. According to Illiashenko et al. (2019), innovative development management depends on different types of innovative strategies and applied approaches. Chukhray (2017) discovered general barriers and key benefits of such a type of innovations as university-business cooperation. Kanishchenko et al. (2019) studied the innovation management problems and paid special attention to the commercialization of environmental innovations at enterprises. Melnyk et al. (2019) offered the stages of the innovation commercialization process and innovative product promotion.
Lyashenko (2009) proposes to understand technology transfer as a process that forms a system of relations between agents of public exchange regarding the transfer of economically beneficial knowledge the recipients intend to use to obtain benefits. This presupposes the transfer of information about the innovation and its transformation into innovation with the active participation of the source of this innovation and the recipients and consumers of the product produced with the help of this information. This, in turn, requires the participants to have a complex of interdisciplinary knowledge and competencies in various fields of science. Boronos et al. (2020) proposed scientific methods to form the strategic guidelines for European integration processes considering predicting indicators of innovative development and international experience.

Fonshteyn (1995) understands the transfer of innovations as the process of interaction and exchange of information between people over a long period, considering the human factor. The similarity between innovation and modernization in the economy is the focus on qualitative improvements (in this sense, the concepts considered are synonymous with the idea of "development"). The difference between them lies in the spatiotemporal scale: the starting point of innovation is a focal point object (organization, scientific, or research organization, etc.) with subsequent diffusion to larger areas, and the starting point for modernization of larger areas (industry, education, agriculture, health, etc.) (Khan, 2018; Medani, 2019; 
Peresadko et al., 2014; O. Shkarupa \& I. Shkarupa, 2019; Voronenko et al., 2017). According to Kaiser and Prange-Gstöhl (2013, a multilevel and intersectoral innovation transfer system can be represented as a system whose elements are resources, skills, competencies, and institutional forms. These elements are essential for generating innovation and transferring it to different geographic and industry levels. Srholec (2010) demonstrates how research on the cross-level transition of innovation from local to global can bring benefits. He argued that the management level of the local innovation system has a direct impact on the probability of successful innovation of the company and that this effect depends on the size of the firm.

Therefore, by analyzing the literature, it can be noted that most scientists consider the innovative development through a process of launching a transfer of technologies and innovations on different levels. In this context, the analytical approach will be used that Geels (2002) has proposed about the methods and results of the multilevel innovation perspective concept. From his point of view, multilevel transfer affects three theoretical levels: niches, modes, and landscapes.

Thus, regulation of the transfer of innovations in the economy consists in a systematic multilevel view of ensuring consistency in time and space of interactions of systems of various levels and processes based on the principles of positive and negative feedback, which will be an outstanding condition for forming the economic effects. Based on previous research (O. Shkarupa \& I. Shkarupa, 2019) and the concept of multilevel perspective on transitions formed by Geels $(2002,2011)$, one believes that the idea of analyzing an effective transfer of innovations is based on a cognitive approach for multilevel connections between stakeholders in the system "business-region-state" (Medani, 2019; Hens et al., 2018a; Hens et al., 2018b).

The authors believe that micro-innovations (as highly specialized segmental object processes) in individual functional units of the economic system have a dual nature (material and energy) and become a catalyst for a chain reaction in the process of transfer. As a result, the target direction of innovation changes, and the range of ultimate beneficiaries of economic growth expands.
This research aims to create a methodologically new progressive scientific foundation for the development of instruments for formalizing macroand micro-environment conditions for specific successful, highly specialized innovations to be catalysts for chain reactions to significantly larger territorial communities that will transform the country's development.

Systemic modernization of the national economy in state regulation is the method of cognition of future regulation objects, the study of their subjective nature, relationships, and internal contradictions (Sineviciene et al., 2018; Vasilyeva et al., 2019). Among the general scientific methods of knowing socio-economic processes, a special place belongs to the structural-functional way, which explores the systemic nature of the related socio-economic phenomenon, analyzing the functions of all the elements that interact within the whole system (Kasztelnik \& Gaines, 2019; Matsenko \& Ovcharenko, 2013).

This research is based on the idea that to stimulate the scaling up of innovations, it is necessary to take into account their multichannel intersectoral and multilevel diffusion of innovations in the economy and choose precisely those stimulating influence channels that guarantee the maximum speed and the highest efficiency of scaling local innovation projects to the level of the national economy. Sharing Melnyk and Kubatko's (2013) ideas that implementation of the concept of a green economy is very necessary, the authors think that at the country level, it depends on a useful model of multichannel intersectoral and multilevel transfer of innovations with concretization of quantitatively measured targets and timelines for its achievement, which provides for the transition from different-purpose local eco-projects to the formation of fullfledged ecoregions, which will lead to the growth of the national economy. The authors' interpretation of the essence of ecological modernization of the national economy (as a process of targeted controlled economic and innovation changes at the sectoral and regional levels of government aimed at increasing the economic potential of the national economy) proved that the scale of innovation, geographical and sectoral diversification are catalysts (Figure 1). 
Growing potential through the diversification of scaling innovations

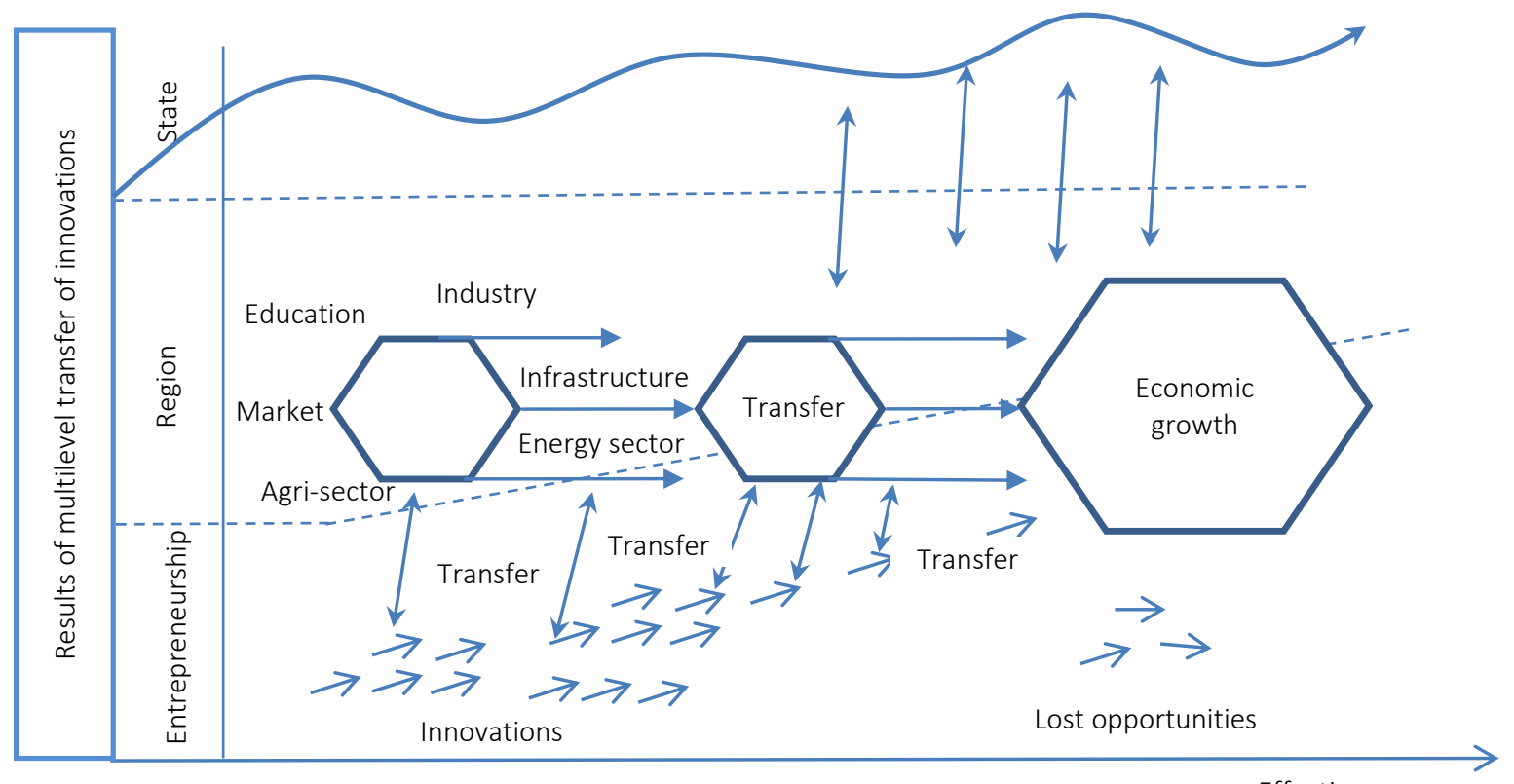

Effectiveness

Figure 1. Multilevel and intersectoral transfer of innovations (authors' view)

An effective transfer of eco-innovation in the company-region-state system depends on stimulating environmentally friendly innovations. Due to multichannel intersectoral and multilevel diffusion, it affects the formation of critical components of the national economy and will improve the state's economic security. The result of this diffusion of eco-innovation is the emergence and spread of systemic multilevel effects, the action of which will significantly increase economic growth. This requires focusing on the targeted nature of transformation processes in the company-region-state system, modeling specific quantitatively measured innovation transfer targets. In the future, this will enable us to identify, formally describe and evaluate the effects that arise as a result of the scaling of innovations, their geographical and sectoral diversification, and exploring the channels of their intersectoral diffusion.

The analysis of the situation in Ukraine for 20102017 based on the EU Statistics data allows talking about certain problems on the part of state regulation of stimulating innovation. In the authors' opinion, little attention is paid to innovative activities on the part of the state, accompanied by a decline in the economy in the regions of Ukraine. The disadvantages of introducing creative activities in the areas of Ukraine are related to the following:
1) introduction of innovative activities without an established system and sequence;

2) insufficient regulation of the regulatory framework for the development of innovation in the regions;

3) low state and regional support for the implementation and development of innovative activities in the areas;

4) underfunding of all areas for the performance and development of creative activities;

5) providing incomplete information on the development of the latest technologies in certain regions.

Compared to the countries of the European Union (most countries have an indicator of more than $50 \%$, and the lowest indicator is more than $20 \%$ ), these indicators of development and increase in innovation are quite small, which affects the destructive processes in the country (Melnyk \& Kubatko, 2013). Table 1 shows an analysis of research funding. The data indicate that R\&D funding in Ukraine is directed primarily towards the public sector, while in the EU, towards the business sector. The funds from foreign sources in 
Table 1. The share of financing of R\&D expenses in the total volume of R\&D expenses by sector

Source: Eurostat (2020).

\begin{tabular}{|c|c|c|c|c|c|c|c|c|c|c|c|c|c|c|c|}
\hline & \multicolumn{3}{|c|}{$\begin{array}{l}\text { Entrepreneurial } \\
\text { sector }\end{array}$} & \multicolumn{3}{|c|}{$\begin{array}{l}\text { Public } \\
\text { sector }\end{array}$} & \multicolumn{3}{|c|}{$\begin{array}{c}\text { Higher education } \\
\text { sector }\end{array}$} & \multicolumn{3}{|c|}{$\begin{array}{c}\text { Private non-profit } \\
\text { sector }\end{array}$} & \multicolumn{3}{|c|}{$\begin{array}{c}\text { Funds from foreign } \\
\text { sources }\end{array}$} \\
\hline & 2010 & 2016 & 2017 & 2010 & 2016 & 2017 & 2010 & 2016 & 2017 & 2010 & 2016 & 2017 & 2010 & 2016 & 2017 \\
\hline EU 28 & 53.8 & 57.0 & 58.2 & 34.8 & 30.2 & 29.3 & 0.9 & 1.2 & 1.1 & 1.6 & 1.6 & 1.7 & 8.9 & 10.0 & 9.8 \\
\hline Ukraine & 23.8 & 36.9 & 30.1 & 49.5 & 39.3 & 44.2 & 0.2 & 0.2 & 0.2 & 0.1 & 0.0 & 0.0 & 25.8 & 22.1 & 24.4 \\
\hline
\end{tabular}

Ukraine are used in 2.5 cases more than in the EU countries.

Simulteneously, the share of R\&D expenditures in the GDP of the EU countries and Ukraine suggests that there is a crisis in Ukraine with the financing of scientific research and the activation of innovation. While almost all European countries adhere to the state policy of increasing expenditures on scientific research, there are negative trends in Ukraine in Ukraine.

The basis for solving the problems that have developed in the field of innovation management is providing society with opportunities for the development of innovation infrastructure. The business sector is the catalyst for introducing innovations and may be interested in scaling up innovations. Society requires adequate space for the formation and development of innovative activities in the regions of Ukraine. The fundamental incentive instruments for the initiation and implementation of innovative projects in Ukraine include the following:

- financing and support of the regions of Ukraine from the state;

- social assistance and benefits in the production of innovative activities;

- support of regions with a low level of innovative activities through government programs;

- creation of optimal conditions for state and domestic investors;

- creation of a reasonable plan for formation, verification, and control of the innovative potential of the regions;

- training and stimulation of qualified personnel for innovative projects.
However, existing management approaches in regulating the transfer of innovations do not sufficiently ensure the quality of measures taken to modernize the economy according to the expected results.

\section{RESULTS}

As the model approach's practice shows, the most significant and, simultaneously, the most difficult tasks are the tasks of analyzing and forecasting the development of the processes of socio-economic interaction. Such tasks are associated with predicting the achievement of long-term goals by adapting to changes in the external environment. To determine the mutual influence of innovations in the national economy system, considering the goal setting for economic growth, it is advisable to apply methods of modeling complex systems.

The study of modeling complex systems using the example of certain components' functioning is not a very difficult task and often almost insoluble by conventional methods due to the different dimensionality of the data needed to build the model. In world practice, "fuzzy logic" (cognitive logic) has been increasingly used to solve such problems. The methodology of analysis and construction of cognitive maps is described in detail in Axelrod (1976), Groumpos and Anninou (2017), Stach et al. (2010), Novak and Cañas (2008), Kokkinos et al. (2018). Thus, according to Kokkinos (2018), FCM is a qualitative reflection of the logical conclusions and dynamic characteristics of the system, as a result of which it is possible to obtain information about the behavior of the system, and in some cases, to carry out numerical experiments.

In other words, FCM is a graphical illustration of the causal relationships identified between the concepts of a certain area, which enables us to describe its functioning symbolically. In the dia- 
grams, conceptual factors represent the system's key characteristics, and lines represent possible relationships between these concepts (Axelrod, 1976). The FCM map connections are logically intertwined by correlating concepts through semantically significant paths that show the cause-andeffect relationship between them. The directed edges of the graph reflect the causal relationships between concepts and determine the degree of influence (weight) of the related concepts (Novak \& Cañas, 2008). The nodes in the graph $C_{i}$ represent the factors, and the edges represent the relationships between the factor's $C_{i}$ and $C_{i}$.

It is advisable to use an expert method to develop FCM. This allows identifying the main factors-concepts and to find out the cause-effect relationships between them. Karaoulanis (2018) and Stach et al. (2010) advise using such actions to create FCM: each expert determines the level of connection between any two concepts characterizing some events, actions, values. Further, the degree of influence between each pair of concepts or the assignment of membership functions on each term is determined. This can be a different type of influence between concepts (Stylios \& Groumpos, 1999; Stach et al., 2010; Stylios et al., 1997; Chen et al., 2015).

Based on the fuzzy cognitive map concept, matrices of mutual influence of concepts on each other are formed (increasing the factor $C_{i}$ 's value leads

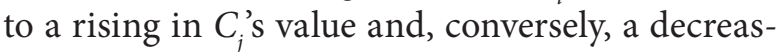
ing in $C_{i}$ decreases $C_{j}$ ), after which the behavior and stability of the constructed map are investigated. System indicators of a fuzzy map are calculated - consonances and dissonances of the influ- ence of concepts on each other, the calculation of which is based on comparing the contours formed from the concepts of the map according to the criterion of conformity, balance, and power of influence (Stylios \& Groumpos, 1999; Stach et al., 2010; Chen et al., 2015).

After determining all the variables, the necessary values, and the relationships between the factors, the algorithm for determining the equilibrium values is as follows:

Step 1. An initial vector $X^{(0)}$ is determined that corresponds to elements based on assumptions and available knowledge. Let us denote the value of all factors $C_{i}, i=1, n$ at the $k$-th step by a vector $X^{(k)}$. Then, at the $k$-1st step, this vector will affect as $X^{(k-1)}$. Then one can use the rule for finding the influence of a factor as follows (Stylios \& Groumpos, 1999):

$$
X^{(k)}=f\left(W^{T} X^{(k-1)}\right),
$$

where $f$ - sigmoid function, $W^{T}$ - transposed matrix.

Step 2. The initial vector $X^{(0)}$ and matrix $W$ are multiplied following the rule:

$$
x_{i}^{(k)}=f\left[\sum_{\substack{j=1 \\ j \neq i}}^{n} x_{j}^{(k-1)} w_{j i}+w_{i i} x_{i}^{(k-1)}\right],
$$

where the values $w_{i i}$ represent the elements of the main diagonal of the matrix $W ; w_{i j}$ - the trans-

Table 2. The values according to the "strength of impact"

\begin{tabular}{|c|c|c|c|}
\hline Type of factors & Type of impact & Strength of impact & Values \\
\hline \multirow{5}{*}{ Factor drivers } & \multirow{5}{*}{ Positive connection } & Very strong & 0.81 to 1 \\
\hline & & Strong & 0.6 to 0.8 \\
\hline & & Average & 0.41 to 0.59 \\
\hline & & Weak & 0.21 to 0.4 \\
\hline & & Very weak & 0 to 0.2 \\
\hline- & Not related & Missing & 0 \\
\hline \multirow{5}{*}{ Depressant factors } & \multirow{5}{*}{ Negative connection } & Very weak & 0 to -0.2 \\
\hline & & Weak & -0.21 to -0.4 \\
\hline & & Average & -0.41 to -0.59 \\
\hline & & Strong & -0.6 to -0.8 \\
\hline & & Very strong & -0.81 to -1 \\
\hline
\end{tabular}

Source: Stylios and Groumpos (1999). 
posed matrix $W^{T}$ (the relationship from $C_{j}$ to $C_{i}$ ). A positive value $w_{i j}>0$ means that an increase in the value of factor $\stackrel{C}{i}_{i}$ leads to an increase in $C_{j}^{\prime}$ s value and vice versa, a decrease in $C_{i}$ decreases $C_{j}$. A negative value means the opposite effect: an increase in the first factor's value leads to a decrease in the second, and vice versa. The value determines the degree of influence of factor $C_{i}$ on $C_{j}, w_{i j}$.

Step 3. The resulting vector $X$ is updated using the FCM methodology.

Step 4. The new vector $X^{(k)}$ is considered the initial one at the next iteration.

Step 5. Steps 2-4 are repeated until the condition is satisfied $X^{(k)}-X^{(k-1)} \leq e=0.001$ (here, the difference is between the vector $X$ elements with the same numbers, and its maximum value is determined).

After the maximum value of the difference between the elements satisfies the condition in step 5, the equilibrium value is found and accepted. Thus, FCM allows us to present high-quality modeling and experiment for a dynamic system (Papageorgiou et al., 2005). This type of simulation provides exploring "what-if" scenarios. It is necessary to carry out modeling for this model at various values of the initial vector. Modeling allows describing the system's dynamic behavior and can be used to make decisions or forecast future states. Therefore, it is proposed to use the methodology of cognitive modeling, which can be the basis for the development of a cognitive model for a system to manage the process of innovation transfer, since, according to Axelrod (1976), Groumpos and Anninou (2017), Stach et al. (2010), Novak and Cañas (2008), Kokkinos et al. (2018), cognitive technologies are considered very promising in the development of weakly structured and poorly formalized systems. Cognitive modeling helps obtain the results quickly, understand the system in more detail, identify patterns, and refine the model. As a result of the analysis of the subject area of eco-innovation transfer and their relationship with economic growth processes, 100 indicators were identified that affect the process of economic development in different sectors of the national economy. It also forms the basis of the economic security management system. It is proposed to form a cognitive model of a new multilevel innovation transfer quality management system using these factors-concepts.
Based on such thoughts, when defining the feedback of the level of expression at the company of each indicator of innovation transfer process - the index values of mutual balance were used. Factorsconcepts and parameters that were evaluated: $x_{1}$ (Economic -6 indicators included), $x_{2}$ (Social -6 indicators included), $x_{3}$ (Eco-friendly innovations 6 indicators included), $x_{4}$ (Natural resource usage 6 indicators included), $x_{5}$ (Institutional -5 indicators included), $x_{6}$ (Demographics -6 indicators included), $x_{7}$ (Scientific development -6 indicators included), $x_{8}$ (Informative -7 indicators included), $x_{9}$ (Production and technology -6 indicators included), $x_{10}$ (Infrastructure for transfer -6 indicators included), $x_{11}$ (Finance -5 indicators included), $x_{12}$ (Organizational and administrative -7 indicators included), $x_{13}$ (Education -4 indicators included), $x_{14}$ (Solidarity -4 indicators included), $x_{15}$ (International collaboration -6 indicators included), $x_{16}$ (Management strategy -6 indicators included), $x_{17}$ (Transfer innovation process -4 indicators included), $x_{18}$ (Promotion and commercialization -4 indicators included). Based on the results of the expert method of assessments, a matrix of the most influential factors was obtained by questioning a group of experts from 120 representatives of the business sector and organizations of different sectors of the national economy and governing bodies of different levels (which generally corresponds to the statistical requirements for the survey and confirms the representativeness of the data). Because of the large size of the matrix (100x100), the peer review results are presented for 18 factors-concepts.

The authors have studied the influence of all indicators on economic growth based on the adjacency matrix, in which experts estimate the values of indicators. To do this, the programming language $\mathrm{R}$ was used to develop a program and implement it in the RStudio. To build cognitive maps, the FCMapper library was used. After the eleventh iteration, values are obtained that satisfy the condition $x_{11}-x_{10} \leq 0.001$. Thus, the values that take the following values will be equilibrium:

Because the three factors lack the power of influence, as their values are $\approx 0.0004$, the authors exclude factors $x_{4}, x_{10}, x_{12}$, and $x_{14}$ and continue the study. 


$$
X^{(1)}=\left(\begin{array}{c}
x_{1}=0.899 \\
x_{2}=0.921 \\
x_{3}=0.932 \\
x_{4}=0.615 \\
x_{5}=0.743 \\
x_{6}=0.802 \\
x_{7}=0.900 \\
x_{8}=0.481 \\
x_{9}=0.656 \\
x_{10}=0.490 \\
x_{11}=0.899 \\
x_{12}=0.460 \\
x_{13}=0.601 \\
x_{14}=0.662 \\
x_{15}=0.991 \\
x_{16}=0.980 \\
x_{17}=-0.791 \\
x_{18}=0.762
\end{array}\right) \ldots X^{(11)}=\left(\begin{array}{c}
x_{1}=0.982 \\
x_{2}=0.817 \\
x_{3}=0.891 \\
x_{4}=0.00042 \\
x_{5}=-0.296 \\
x_{6}=0.768 \\
x_{7}=0.410 \\
x_{8}=-0.245 \\
x_{9}=0.538 \\
x_{10}=0.0004 \\
x_{11}=0.929 \\
x_{12}=0.0004 \\
x_{13}=0.098 \\
x_{14}=0.0004 \\
x_{15}=0.936 \\
x_{16}=0.923 \\
x_{17}=-0.879 \\
x_{18}=0.861
\end{array}\right)
$$

Source: Authors' research.

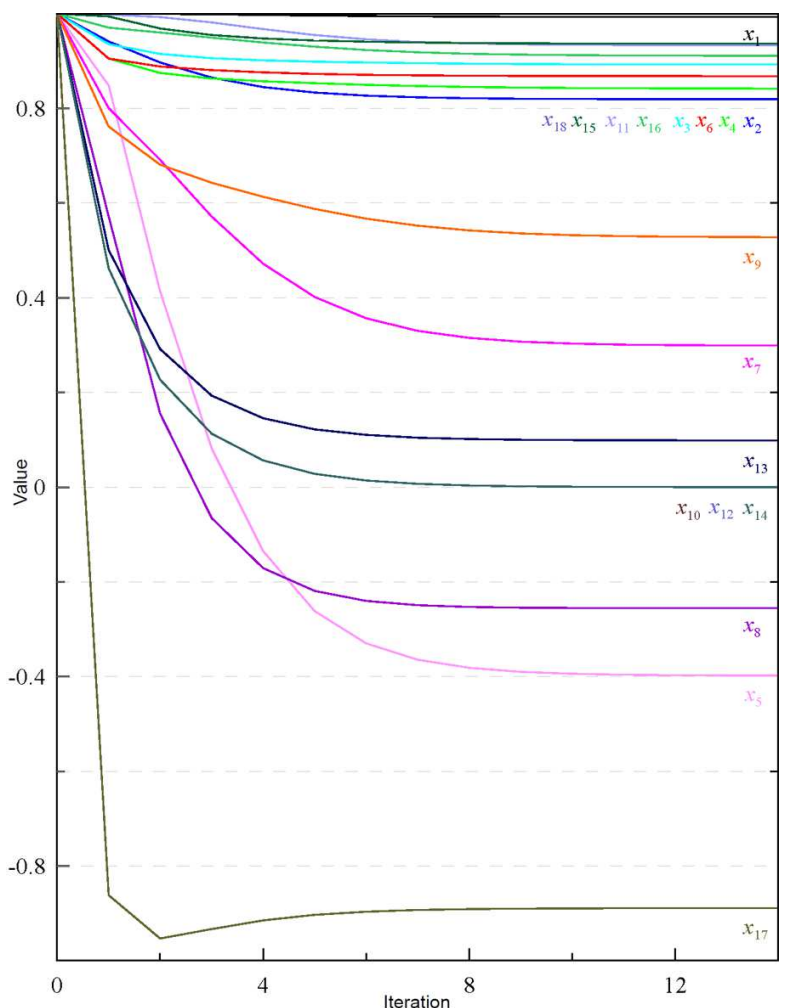

Figure 2. Results of the 1-14 iterations

\section{DISCUSSION}

All positive relationships between factors on the graph curves are black, negative - red. The absence of "loops" indicates the fact that none of the factors affect itself. The "strength of impact" depends on the thickness of the graph curves: for the minimum thickness is the smallest, for the largest impact - the largest (Figure 3).

Thus, all elements can be classified by "strength of impact": the factors $x_{1}, x_{2}, x_{3}, x_{6}, x_{11}, x_{15}, x_{16}, x_{18}$ have a powerful positive effect; average positive impact $-x_{9}$; weak positive $-x_{7}$; very weak positive $-x_{13}$; no influence $-x_{10}, x_{12}$; weak negative influence $-x_{5}, x_{8}$; very strong negative impact $x_{17}$. The use of a cognitive approach to solving the problems of transfer of innovations and intersectoral interaction as priority factors in developing economic systems based on the conjugation of these categories enabled us to form an imitation cognitive model of a multilevel transfer of innovations (Figure 3).
Using the FCM approach will allow:

1) identifying the concepts that significantly affect the innovation transfer system;

2) improving the efficiency of planning the development of information technology in the region;

3) increasing the efficiency of innovation, transfer processes, optimize them, and improve them by changing the parameters that affect the essential components' functioning;

4) investigating the system's structure and obtain forecasts of its behavior under various control influences to find optimal control strategies;

5) predicting the state of the system in time and assess the current situation;

6) assessing the possible consequences of management decisions and determine whether 


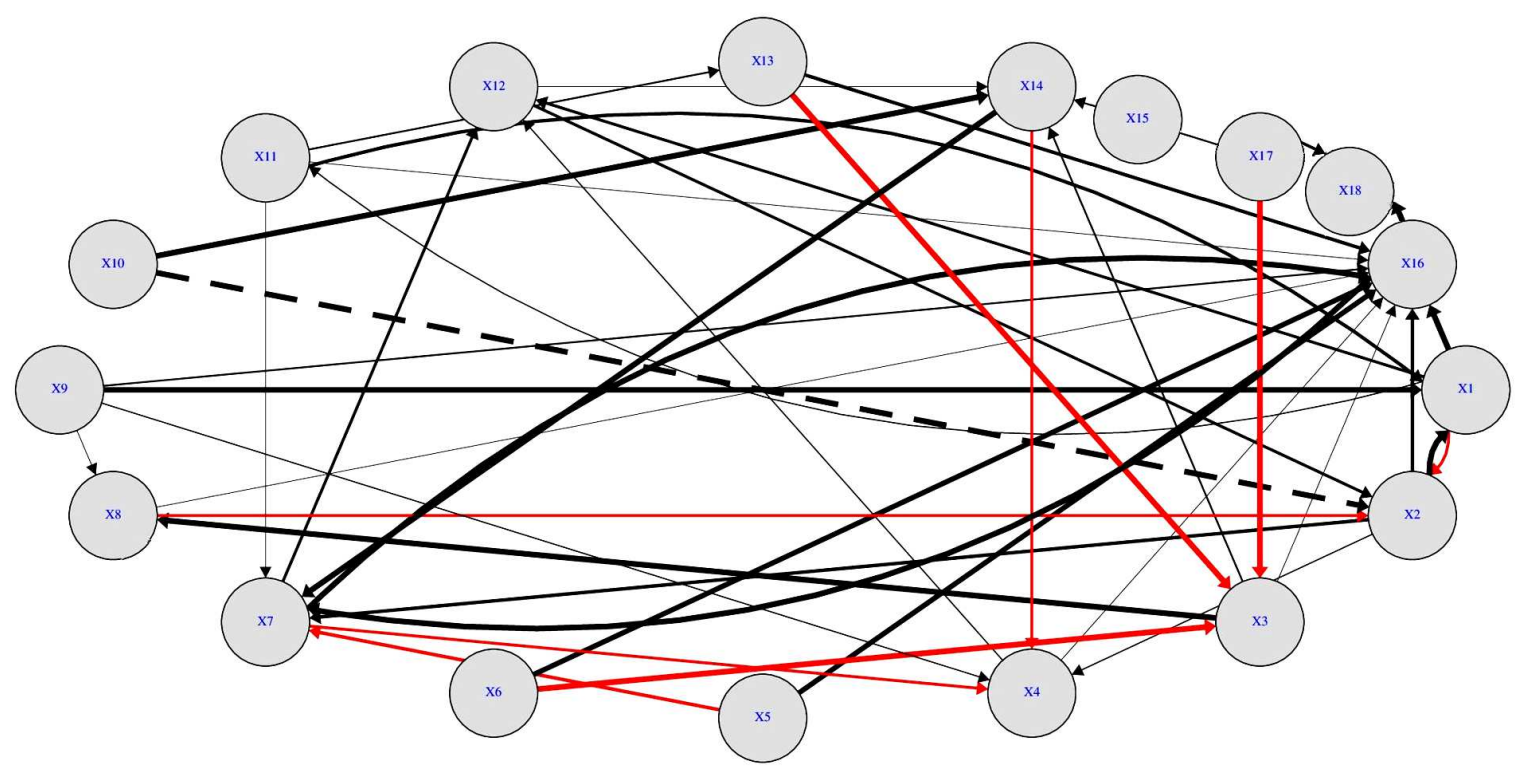

Figure 3. Cognitive map of multilevel transfer of innovations in Ukraine

these decisions can destabilize the system and what qualitative changes will occur in concepts after these decisions are implemented.

This cognitive model can predict changes in the structure of innovation development. The potential and rate of change in intersectoral relations in transferring innovations will allow regional authorities to propose programs and projects of the state and quasi-regional regulation of the development for the different sectors of the economy. So, this approach can be used to conceptualize and model complex economic and social relations in the multilevel transfer system of innovations. In practical terms, the resulting cognitive model can be used to develop management strategies, program documents for the strategic development of a country, region, company, etc. This is also a toolkit for monitoring the situation and testing hypotheses of mechanisms for the development of innovations' multilevel transfer.

\section{CONCLUSION}

The main goal of managing the innovation sphere for economic growth is to systematically regulate the introduction of innovative changes - plans and projects, ensure the efficient transfer process that will provide the further financial process, and increase the competitiveness of the national economy. The present study investigated the factors influencing the economic growth of the country in such components of the national economy: "company" as a microenvironment, "region" - as a place of strategic support for innovative activity of business and "state" - as a subject of regulation efficiency of productive transformations in the national economy of the country.

This study reveals that the government's role is strong in supporting the multilevel transfer of innovations. Together with the management tools, the government can help to enhance the transfer innovation process for economic growth. For it, the scientific basis for making managerial decisions on the choice of the most influential channels of state regulation in the process of innovation transfer based on the application of cognitive modeling tools has been developed. This enabled us to identify the factors through which the implementation of regulatory influences will become a catalyst/inhibitor of the effectiveness of multilevel innovation transfer. The authors believe that tappropriate instruments of state regulation will support the multilevel transfer of innovations 
within the framework of the task of making effective decisions for economic growth In the further analysis, the authors will focus on how intersectoral actions affect the transfer process of innovations and what measures can be implemented in different sectors.

\section{AUTHOR CONTRIBUTIONS}

Conceptualization: Olena Shkarupa.

Data curation: Dmytro Vlasenko, Kostiantyn Fedchenko.

Formal analysis: Viktoriia Boronos, Dmytro Vlasenko.

Funding acquisition: Olena Shkarupa, Viktoriia Boronos.

Investigation: Viktoriia Boronos, Kostiantyn Fedchenko.

Methodology: Olena Shkarupa.

Project administration: Olena Shkarupa.

Resources: Olena Shkarupa, Viktoriia Boronos, Dmytro Vlasenko, Kostiantyn Fedchenko.

Software: Dmytro Vlasenko.

Supervision: Olena Shkarupa.

Validation: Kostiantyn Fedchenko.

Visualization: Kostiantyn Fedchenko.

Writing - original draft: Olena Shkarupa.

Writing - review \& editing: Viktoriia Boronos.

\section{ACKNOWLEDGMENT}

This research was funded by a grant from the Ministry of Education and Science of Ukraine "Modelling the Transfer of Eco-Innovations in the Enterprise-Region-State System: Impact on Ukraine's Economic Growth and Security" (No. 0119U100364).

\section{REFERENCES}

1. Axelrod, R. (1976). The analysis of cognitive maps. In R. Axelrod (Ed.), Structure of Decision: The Cognitive Maps of Political Elites (pp. 55-73). Princeton, NY: Princeton University Press.

2. Boronos, V. G., Shkarupa, O. V., Demchyshak, N. B., Sineviciene, L., \& Kubakh, T. G. (2020). Strategic orientation of innovative activity regulation: Ukraine and EU integration process. Financial and credit activity: problems of theory and practice, 1(32), 307-318.

3. Chen, Z., Yan, Y., Hao, J., \& Wang, G. (2015). Fuzzy Cognitive MapsBased Method for Modelling Tacit Knowledge of Scheme Evaluation. In Proceedings 2015 International Symposium on Material, Energy and Environment Engineering (pp. 570-573). https://doi.org/10.2991/ ism3e-15.2015.137

4. Chukhray, N. I. (2017). Barriers and benefits of university-business cooperation in Ukrainian innovation sector. Naukovyi visnyk Mizhnarodnoho humanitarnoho universytetu - Scientific Bulletin of the International Humanities University, 25(2), 21-24. (In Ukrainian). Retrieved from http:// nbuv.gov.ua/UJRN/Nvmgu_ eim_2017_25\%282\%29_7

5. European Commission (EC). (2018). European Innovation Scoreboard 2018. Retrieved from https://op.europa.eu/ en/publication-detail/-/ publication/8e458033-74fc-11e89483-01aa75ed71a1/language-en/ format-PDF/source-99539237

6. Eurostat. (2018). Research and development expenditures. Retrieved from http://ec.europa. eu/eurostat/statistics-explained/ index.php/R_\%26_D_expenditure

7. Eurostat. (2020). Waste generated by households by year and waste category. Retrieved from https:// ec.europa.eu/eurostat/web/products-datasets/-/ten00110

8. Fonshteyn, N. M. (1995) Commercialization of technologies. World experience for Russian regions. Moscow: Moscow News. (In Russian)

9. Geels, F. W. (2002). Technological transitions as evolutionary reconfiguration processes: a multilevel perspective and a case-study. Research Policy, 31(8-9), 1257-1274. https://doi.org/10.1016/S00487333(02)00062-8

10. Geels, F. W. (2011). The multilevel perspective on sustainability transitions: responses to seven criticisms. Environmental Innovation and Societal Transitions, 1(1) 24-40. https://doi.org/10.1016/j. eist.2011.02.002

11. Groumpos, P., \& Anninou, A. (2017). A critical overview of 
modeling methods and decision support systems for complex dynamic systems. Annals of Faculty Engineering Hunedoara, 15(3), 17-26. Retrieved from http://annals.fih.upt.ro/pdf-full/2017/ANNALS-2017-3-01.pdf

12. Hens, L., Karintseva, O., Kharchenko, M., \& Matsenko, O. (2018a). The States Structural Policy Innovations Influenced by the Ecological Transformations. Marketing and Management of Innovations, 3, 290-301. http://doi. org/10.21272/mmi.2018.3-26.

13. Hens, L., Karintseva, O., Shkarupa, O., \& Kharchenko, M. (2018b). Integral assessment of national economy sustainable development. International Journal of Environmental Technology and Management, 21(5/6), 306-318. https://dx.doi.org/10.1504/ IJETM.2018.100588

14. Illiashenko, S., Shypulina, Yu., Gryshchenko, O., \& Illiashenko, N. (2019). The information support system's formation of marketing innovative decisions in Ukrainian companies. International Journal of Recent Technology and Engineering, 8(3C), 137-143. https://doi.org/10.35940/ijrte. C1023.1183C19

15. Jordan, J. F. (2014). Innovation, Commercialization, and the Successful Startup (1st ed.). CRC Press.

16. Kaiser, R., \& Prange-Gstöhl, H. (2013). Multilevel Systems of Innovation. In E. G. Carayannis (Ed.), Encyclopedia of Creativity, Invention, Innovation and Entrepreneurship. Springer, New York, NY. https://doi. org/10.1007/978-1-4614-38588_311

17. Kanishchenko, O., Chupryna, N., Bobkova, A., Andryeyeva, N., \& Kozlovtseva, V. (2019). Problems of Commercialization of Environmental Innovations at Industrial Enterprises. International Journal of Recent Technology and Engineering, 8(4), 11216-11220. https://doi. org/10.35940/ijrte.D8892.118419

18. Karaoulanis, A. (2018). Strategic Transformation and Innovation towards Blue Ocean Creation in a Changing Corporate Reality. Business Ethics and Leadership, 2(2), 49-55. https://doi. org/10.21272/bel.2(2).49-55.2018

19. Kasztelnik, K., \& Gaines, V. W. (2019). Correlational Study: Internal Auditing and Management Control Environment Innovation within Public Sector in the United States. Financial Markets, Institutions and Risks, 3(4), 5-15. http://doi. org/10.21272/fmir.3(4).5-15.2019

20. Khan, Y. H. (2018). The Effectiveness of Entrepreneurial Activities for Economic Development: A Route to Innovation and Job Generation. Socio-Economic Challenges, 2(2), 32-40. http://doi.org/10.21272/ sec.2(2).32-40.2018

21. Kokkinos, K., Lakioti, E., Papageorgiou, E., Moustakas, K., \& Karayannis, V. (2018). Fuzzy Cognitive Map-Based Modeling of Social Acceptance to Overcome Uncertainties in Establishing Waste Biorefinery Facilities. Frontiers in Energy Research, 6, 112. http://doi.org/10.3389/fenrg.2018.00112

22. Lyashenko, O. M. (2009). Metody ta modeli komertsializatsiyi transferu tekhnolohiy [Methods and models of commercialization of technology transfer] (Doctoral Thesis). (In Ukrainian). Retrieved from http://dspace.wunu.edu.ua/ bitstream/316497/3051/1/secur lyashenko_doc_aref.pdf

23. Matsenko, O., \& Ovcharenko, D. (2013). The Quality of Energy Resources Controlling as a Part of Effective Enterprise Management. Economic AnnalsXXI, 9-10(1), 75-78. Retrieved from http://essuir.sumdu.edu.ua/ handle/123456789/74620

24. Medani P. Bhandari. (2019). Sustainable Development: Is This Paradigm the Remedy of All Challenges? Does its Goals Capture the Essence of Real Development and Sustainability? With Reference to Discourses, Creativeness, Boundaries and Institutional Architecture. Socio-Economic Challenges, 3(4), 97-128. http://doi.org/10.21272/ sec.3(4).97-128.2019
25. Melnyk, L. G., \& Kubatko, O. V. (2013). The EU experience in economic systems adaptation to resource fluctuations through stimulation of green innovations. Actual Problems of Economics, 150(12), 36-42. Retrieved from https://www.researchgate.net/ publication/287956035_The_eu_ experience_in_economic_systems_adaptation_to_resource_ fluctuations_through_stimulation_of_green_innovations

26. Melnyk, Yu. M., Sager, L. Yu., \& Sygyda, L. O. (2019). Teoretychni aspekty formuvannia stratehii komertsializatsii innovatsiinoi produktsii [Theoretical aspects of strategies forming for innovative products commercialization]. Visnyk Odeskoho natsionalnoho universytetu imeni O.O. Mechnykova - Bulletin of Odesa I. I. Mechnikov National University, 1(74), 69-73. (In Ukrainian). Retrieved from http://visnyk-onu. od.ua/journal/2019_24_1/15.pdf

27. Novak, J. D., \& Cañas, A. J. (2008). The theory underlying concept maps and how to construct and use them (Technical Report IHMC CmapTools 2006-01 Rev 01-2008). Florida Institute for Human and Machine Cognition, Pensacola, Florida. Retrieved from http:// cmap.ihmc.us/publications/ researchpapers/theoryunderlyingconceptmaps.pdf

28. Papageorgiou, E. I., Parsopoulos, K. E., Stylios, C., Groumpos, P. P., \& Vrahatis, M. N. (2005). Fuzzy Cognitive Maps Learning Using Particle Swarm Optimization. Journal of Intelligent Information Systems, 25(1), 95-121. Retrieved from https://link.springer.com/article/10.1007/s10844-005-0864-9

29. Peresadko, G. O., Kovalenko, E. V., \& Kulyk, L. A. (2014). Mechanisms of investing into innovative projects of enterprises. Actual Problems of Economics, 160(1), 184-187. Retrieved from https://www.researchgate.net/ publication/297884615_Mechanisms_of_investing_into_innovative_projects_of_enterprises

30. Peshko, A. V., \& Nazarenko, A. V. (2006). Innovative activities as a necessary component 
of investments. Ekonomika promyslovosti-Industrial economics, 2, 14-18. (In Ukrainian). Retrieved from http://dspace.nbuv.gov.ua/handle/123456789/2782

31. Porter, M. (1993). Mezhdunarodnaya konkurentsiya [International competition] (896 p.). Moscow: Mezhdunarodnye otnosheniya. (In Russian)

32. Shkarupa, O., \& Shkarupa, I. (2019). Regulation the multilevel transfer system of innovations for sustainable development. Paper presented at the 60th International Scientific Conference of Riga Technical University "Scientific Conference on Economics and Entrepreneurship SCEE'2019”. Book of Abstracts (54 p.). Riga: RTU Press. https://doi. org/10.7250/scee.2019.009

33. Sineviciene, L., Shkarupa, O., \& Sysoyeva, L. (2018). Socio-economic and Political Channels for Promoting Innovation as a Basis for Increasing the Economic Security of the State: Comparison of Ukraine and the Countries of the European Union. Socio-Economic Challenges, 2(2), 81-93. https://doi. org/10.21272/sec.2(2).81-93.2018

34. Srholec, M. (2010). A Multilevel Approach to Geography of Innovation. Regional Studies,
44(9), 1207-1220. https://doi. org/10.1080/00343400903365094

35. Stach, W., Kurgan, L. A., \& Pedrycz, W. (2010). Expertbased and Computational Methods for Developing Fuzzy Cognitive Maps. In M. Glykas (Ed.), Fuzzy Cognitive Maps: Advances in Theory, Methodologies and Applications. Springer. Retrieved from https://link.springer.com/chapter/10.1007/978-3-642-03220-2_2

36. Stylios, C., \& Groumpos, P. P. (1999). Mathematical Formulation of Fuzzy Cognitive Maps. In Proceedings of the 7th Mediterranean Conference on Control and Automation (MED99) (pp. 2251-2261). Haifa, Israel. Retrieved from https:// www.researchgate.net/publication/228567505_Mathematical_formulation_of_fuzzy_cognitive_maps

37. Stylios, C., Georgopoulos, V. C., \& Groumpos, P. P. (1997). The Use of Fuzzy Cognitive Maps in Modeling Systems. Proceedings of the 5th Mediterranean Conference on Control and Systems. Paphos, Cyprus. Retrieved from https:// www.researchgate.net/publication/237085462_The_Use_of_ Fuzzy_Cognitive_Maps_in_Modeling_Systems
38. Vasilyeva, T., Kuzmenko, O., \& Bozhenko, V. (2019). Assessment of the dynamics of bifurcation transformations in the economy. Paper presented at the $8^{\text {th }}$ International Conference on Monitoring, Modeling \& Management of Emergent Economy (M3E2 2019) (pp. 134146). https://doi.org/10.1051/ shsconf/20196504006

39. Verkhovna Rada of Ukraine. (2002). Pro innovatsiinu diialnist [On Innovation Activity]. The Law of Ukraine No. 40-IV of July 4, 2002. Retrieved from https://zakon.rada.gov.ua/laws/ show/40-15

40. Voronenko, V., Kovalov, B., Horobchenko, D., \& Hrycenko, P. (2017). The effects of the management of natural energy resources in the European Union. Journal of Environmental Management and Tourism, 8(7), 1410-1419. Retrieved from https://journals.aserspublishing. eu/jemt/article/view/1777

41. Zakutniaia, A., \& Hayriyan, A. (2017). Transparency as competitive advantage of innovation driven companies. Business Ethics and Leadership, 1(1), 46-54. https://doi. org/10.21272/bel.2017.1-06 